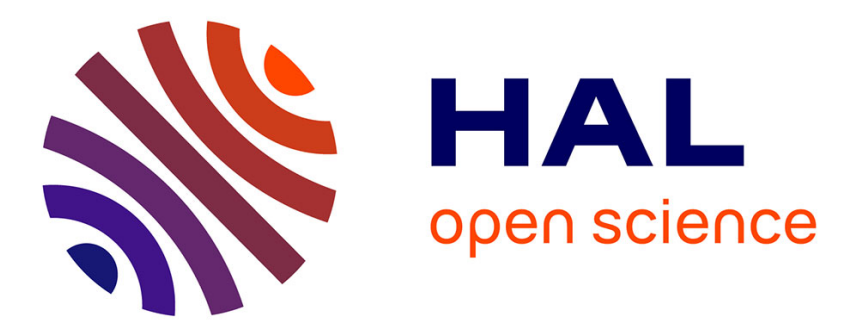

\title{
MAGNETO-OPTICAL STUDIES OF SEMICONDUCTORS WITH AN OPTICALLY PUMPED FAR INFRARED LASER
}

F. Muller, S. Huant, K. Karrai, G. Dampne, M. Grynberg, Gines Martinez Garcia, L. Brunel

\section{To cite this version:}

F. Muller, S. Huant, K. Karrai, G. Dampne, M. Grynberg, et al.. MAGNETO-OPTICAL STUDIES OF SEMICONDUCTORS WITH AN OPTICALLY PUMPED FAR INFRARED LASER. Journal de Physique Colloques, 1987, 48 (C7), pp.C7-717-C7-719. 10.1051/jphyscol:19877176 . jpa-00227000

\section{HAL Id: jpa-00227000 https://hal.science/jpa-00227000}

Submitted on 1 Jan 1987

HAL is a multi-disciplinary open access archive for the deposit and dissemination of scientific research documents, whether they are published or not. The documents may come from teaching and research institutions in France or abroad, or from public or private research centers.
L'archive ouverte pluridisciplinaire HAL, est destinée au dépôt et à la diffusion de documents scientifiques de niveau recherche, publiés ou non, émanant des établissements d'enseignement et de recherche français ou étrangers, des laboratoires publics ou privés. 
JOURNAL DE PHYSIQUE

Colloque C7, supplément au $\mathrm{n}^{\circ} 12$, Tome 48 , décembre 1987

MAGNETO-OPTICAL STUDIES OF SEMICONDUCTORS WITH AN OPTICALLY PUMPED FAR INFRARED LASER

F. MULLER, S. HUANT, K. KARRAI, G. DAMPNE, M. GRYNBERG (1),

G. MARTINEZ and L.C. BRUNEL

Service National des Champs Intenses(2), CNRS et Celphyra. $B P 166 \mathrm{X}, \mathrm{F}-38042$ Grenoble Cedex, France

We first describe the optically pumped Far Infrared laser we developed. We present a list of a number of experimetal works done with the laser. We then describe in more details an original experiment : E.P.R. studies under High Magnetic Fields.

\section{THE FAR INFRARED LASER (F.I.R) Fig. 1}

We used a PL4 Edinburgh $\mathrm{CW} \mathrm{CO}_{2}$ laser. The pump radiation is chopped at typically 40 to $80 \mathrm{~Hz}$ and then focused into the waveguide cavity made of a $1.5 \mathrm{~m}$ long, $17 \mathrm{~mm}$ inner diameter Pyrex tube placed between two mirrors. The F.I.R. output stability was greatly improved using the passive isolator described by Mansfied et al. (1). With such a device the pump radiation is circularly polarized, no attempt was made to check the polarization of the emitted radiation. Depending upon the region of interest we used two waveguide cavities. In the short wavelength region $30-70 \mu \mathrm{m}$, in order to obtain a good stability of the optical FIR resonator the cavity was designed with one flat and one concave mirror (2). The fixed mirror was a flat gold plated brass mirror with a $1.5 \mathrm{~mm}$ central hole, the movable mirror was an aluminized glass mirror with a $3 \mathrm{~m}$ radius of curvature. In this region we used the in/out coupling system described by sigg et al (3). Above $100 \mu \mathrm{m}$ we obtained higher FIR output power using the same fixed mirror and for the FIR output a movable mirror made of a flat aluminized glass mirror with a $4 \mathrm{~mm}$ central hole. In the intermediate region we used either one of the two waveguide cavities.

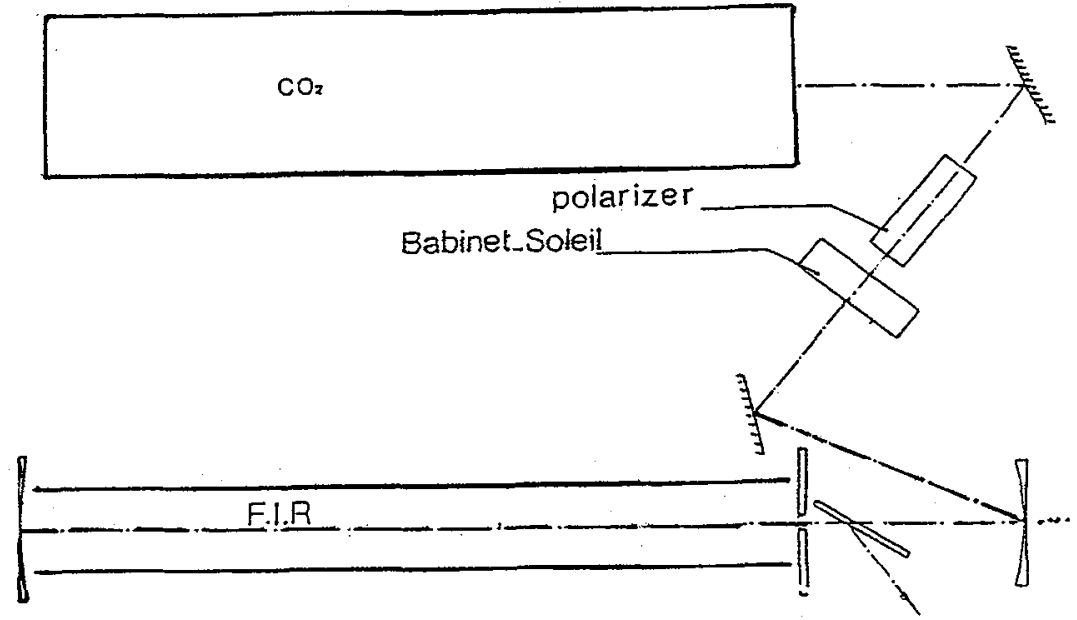

FIG. I FAR INFRARED LASER

(1) Permanent adoress : Institute of Experimental Physics, Warsaw University, Hoz 69, PL-00-681 Warsaw, Poland

(2) Laboratoire associe a 1 'USTMG 


\section{MAGNETO-OPTICAL STUDIES}

We performed magneto-optical studies of a narrow gap semiconductor $n$-In Sb under hydrostatic pressure. Our research work is now mainly focused on twodimensional systems : resonant polaron effect in Ga In As based heterostructures, effect of magnetic field reversal on far infrared resonances, determination of the donor profile in selectively doped GaAs - GaAlAs multiple quantum wells, study of GaAs - AlAs superlattices (in collaboration with R. Planel, F. Mollot, $G$. Danan L2M Bagneux).

\section{ELECTRON PARAMAGNETIC RESONANCE AT HIGH MAGNETIC FIELDS (EPR)}

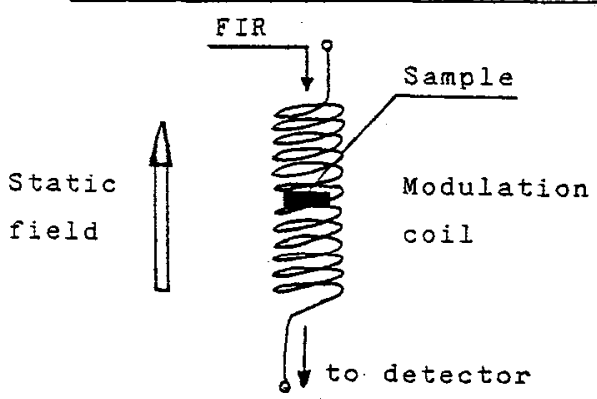

We developed a magnetic field modulation technique for far infrared transmission in the wavelength range. $0,5-2 \mathrm{~mm}$ in order to perform EPR spectroscopy at high magnetic fields. $(0-20 \mathrm{~T})$.

In order to determine the sensitivity and resolution of the experimental set up we used n-type Phosphorus doped Siticon. On Fig 2 a is the modulated spectrum for a $P$ concentration of $2.1018 . \mathrm{cm}^{-3}$. The complexity of the spectrum is due to interactions between impurities. This spectrum shows that we can observe lines of a width of 5 gauss around $10 \mathrm{~T}$. On fig. $2 \mathrm{~b}$ is the spectrum for a $P$ concentration of $1016 \mathrm{~cm}^{-3}$ which is the lower limit in concentration we can detect.

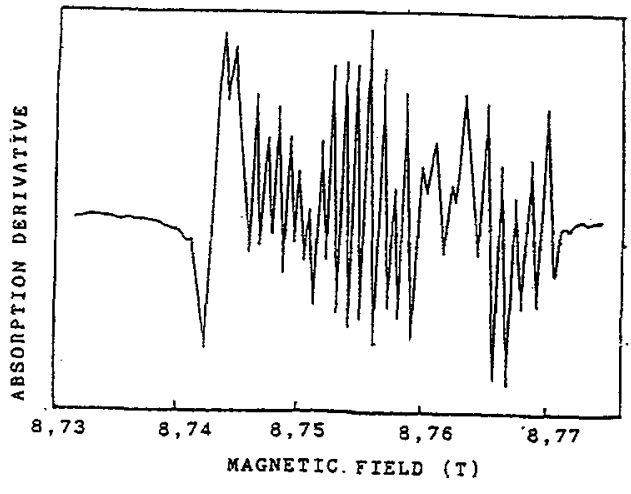

(a)

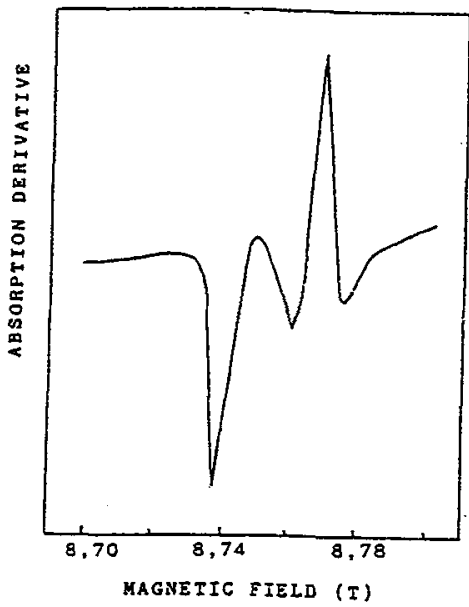

(b)

Fig 2 MODULATED SPECTRA OF $P$ doped Si (see text) 
$5.10^{-4}$ in conclusion the EPR under high magnetic fields has a resolution of comparable with EPR at 9 Ghz. We need relatively high concentration sampies. The advantages are to observe both ED and $M D$ transitions and to work in a wide range of magnetic fields this enables us to study relaxation processes versus field.

\section{References}

1 D.K. Mansfield, A. Semet, L.C. Johnson Appl. Phys. Lett $37(1980) 688$

2 A. Yariv in "Quantum Electronics" (John Wiley and Sons, New-York) 1986

3 H. Sigg, H.J.A. BTuyssen, P. Wyder IEEE J. Quantum Electronics QE 20, vol. 6 (1984) 30. 